\title{
Osteoprotegerin in Human Milk: A Potential Role in the Regulation of Bone Metabolism and Immune Development
}

\author{
KARINE VIDAL, PETER VAN DEN BROEK, FLORENCE LORGET, AND \\ ANNE DONNET-HUGHES \\ Nestec Limited, Nestlé Research Center, Food Immunology, and Metabolic \& Genetic Regulation, \\ Vers-chez-les-Blanc, CH-1000 Lausanne 26, Switzerland
}

\begin{abstract}
Osteoprotegerin (OPG) is a member of the tumor necrosis factor superfamily. It is a soluble "decoy" receptor for tumor necrosis factor-related apoptosis-inducing ligand and ligand of the receptor activator of NF- $\kappa \mathrm{B}$. As such, OPG inhibits osteoclast activity and regulates the immune system. Human milk is a complex biologic fluid that supplies nutritional and protective factors to the breast-fed infant. In the present study, human milk samples at various times postpartum were assessed for the presence of OPG. Using biochemical as well as immunologic and biologic techniques we showed that human milk contains OPG at a level that is 1000 -fold higher than that found in normal human serum. We observed that human breast milk cells and the human mammary epithelial cell line MCF-7 express OPG, indicating that both cell types are possible sources of milk OPG in vivo. In vitro studies demonstrated that milk OPG is biologically active and suggested that it may contribute to the antiresorptive activity
\end{abstract}

ABSTRACT

of milk on bone, as well as tumor necrosis factor-related apoptosis-inducing ligand-induced inhibition of $\mathrm{T}$ cell proliferation. OPG-like activity was also observed in bovine colostrum and milk. Furthermore, we were able to detect human OPG in the sera of rats gavaged with human milk. We discuss the relevance of our findings for the breast-fed infant and for the prevention of immune and bone disorders. (Pediatr Res 55: 1001-1008, 2004)
Abbreviations
HBMC, human breast milk cells
OPG, osteoprotegerin
RANKL, receptor activator of NF- $\kappa \mathrm{B}$ ligand
TACE, TNF- $\alpha$-converting enzyme
TGF, transforming growth factor
TNF, tumor necrosis factor
TRAIL, TNF-related apoptosis-inducing ligand

Members of the tumor necrosis factor (TNF) and TNF receptor superfamilies are instrumental in the regulation of immune homeostasis in multiple sites of the body and as such are the main targets for therapies against a range of human diseases. The receptor activator of NF- $\kappa \mathrm{B}$ (RANK) and its ligand (RANKL) are among the most recently described molecules of the TNF family. They have intrinsic roles to play in the development of immune responses by modulating the survival of dendritic cells and their antigen presentation to $\mathrm{T}$ cells $(1,2)$. The absence of peripheral and mesenteric lymph nodes in animals that lack either of these genes strongly suggests that signaling through these molecules is a prerequi-

Received May 19, 2003; accepted December 4, 2003

Correspondence: Karine Vidal, Ph.D., Nestec Limited, Nestlé Research Center, Food Immunology, Vers-chez-les-Blanc, P.O. Box 44, CH-1000 Lausanne 26, Switzerland; e-mail address: karine.vidal@rdls.nestle.com

Current address (P.v.d.B.): Primagen Holding B.V., Meibergdreef 59, 1105 BA Amsterdam, The Netherlands.

Current address (F.L.): Department of Growth \& Development, University of California at San Francisco, San Francisco, CA 94143, U.S.A.

DOI: 10.1203/01.pdr.0000127014.22068.15 site for normal development of these lymphoid organs $(3,4)$. Furthermore, both molecules are recognized as key regulators in bone remodeling and the development and activation of osteoclasts (5).

Osteoprotegerin (OPG), also known as osteoclastogenesis inhibitory factor, is a naturally occurring soluble member of the TNF receptor family $(6-8)$ that functions as a secreted "decoy" receptor for RANKL (5) and for at least one other TNF family member, TNF-related apoptosis-inducing ligand (TRAIL) (9), an inducer of apoptosis for a variety of cell lines (10). It has been shown that OPG inhibits osteoclastogenesis in vitro, prevents osteoporosis (11), and regulates B cell maturation and the development of efficient antibody responses (12). OPG therefore represents a natural regulator of a variety of cellular processes in bone metabolism and in the immune system.

The neonatal period is particularly critical for the processes governing normal bone remodeling and the development of immune responses. Osteogenesis is a dynamic process that exceeds resorption during the neonatal period and thereby ensures that bone formation parallels the rapid changes in size 
and weight during infancy. At the same time, the developing neonatal immune system must tolerate self-antigens and the succession of bacterial species that constitute the normal intestinal flora but remain vigilant against potentially harmful antigens. It follows that interaction among RANK, RANKL, and OPG may influence how these adaptive processes can occur without any untoward effects.

OPG is widely expressed in multiple tissues, including the respiratory and gastrointestinal tracts, skin, calvarias, smooth muscles, and lymphoid tissues $(6,13,14)$, as well as in mammary gland epithelial cells (15). Because RANK and RANKL are expressed in mammary gland tissue and their signals are regulated by the secreted protein OPG, we sought the presence of OPG in human milk. We hypothesized that a milk-derived OPG may influence immune development and bone homeostasis in the infant and immune mechanisms in the mammary gland and, if present in bovine milk, may also be useful in therapies for bone and immune disorders.

\section{METHODS}

Cell lines and reagents. The human mammary cell line MCF-7 and the human osteosarcoma cell line SaOS-2 [American Type Culture Collection (ATCC), Manassass, VA] were maintained at $37^{\circ} \mathrm{C}$ and $5 \% \mathrm{CO}_{2}$ in Dulbecco's modified Eagle's medium supplemented with 10\% FCS (Amimed, BioConcept, Allschwill, Switzerland). Jurkat cells (ATCC) were maintained in RPMI 1640 modified by ATCC and supplemented with $10 \%$ FCS. In some experiments, MCF-7 cells were incubated for $48 \mathrm{~h}$ with TNF- $\alpha$, transforming growth factor- $\beta 2$ (TGF- $\beta 2$ ), IL-18, leptin (R\&D Systems, Oxon, England), IL-1 $\beta$ (Roche Diagnostics, Rotkreuz, Switzerland), PTH, 17 $\beta$-estradiol (Sigma Chemical Co., St. Louis, MO), or 1,25-dihydroxyvitamin $\mathrm{D}_{3}$ (calcitriol; Alexis, Läufelfingen, Switzerland).

Milk and serum samples. After ethical committee approval and informed consent, human milk was collected aseptically from healthy donors using a breast pump and then fractionated. First, the cellular pellet was obtained by centrifugation $(200 \times$ $g$ for $10 \mathrm{~min}$ ), then the cream was extracted from the remaining milk by high-speed centrifugation $(13,600 \times g$ for $30 \mathrm{~min}$ at $4^{\circ} \mathrm{C}$ ). The skimmed milk was then heated at $35^{\circ} \mathrm{C}$ for $50 \mathrm{~min}$ in the presence of rennet (Rhône Poulenc Rorer, Melun, France) before centrifugation $(13,600 \times g$ for $30 \mathrm{~min})$ to separate the sweet whey from the nonsoluble rennet casein. The casein was then dispersed in $2 \mathrm{mM} \mathrm{CaCl}_{2}, 0.9 \% \mathrm{NaCl}$. Normal human serum was purchased from Sigma Chemical Co. Bovine colostrum and bovine milk were collected from animals kept in local farms.

Cytospin cell preparation and immunocytochemistry. Human breast milk cells (HBMC) were harvested from a fresh human milk sample collected 2 mo postpartum using the protocol above. After washes in PBS, the HBMC were deposited onto clean microscope slides by centrifugation $(1500 \mathrm{rpm}$, 5 min) using a Cytospin (Shandon Inc.). Slides were air-dried, and before use, the cells were fixed in acetone for $5 \mathrm{~min}$ at room temperature. Indirect staining with biotin-labeled goat anti-OPG Ab (R\&D Systems) was performed using the Cata- lyzed Signal Amplification System (Dako). Cells were counterstained with Mayer's hematoxylin.

RT-PCR amplification. DNase-treated RNA was reversetranscribed with MuLV reverse transcriptase (RT) (PerkinElmer, Heunenberg, Switzerland) following the manufacturer's instructions. RT products were amplified with Gold DNA polymerase (Perkin-Elmer) on a thermocycler (Biolabo, Scientific Instruments, Chatel St Denis, Switzerland). Primers for OPG were as follows: 5'-ACTAGTTATAAGCAGCTTATTTTTACTG-3' and 5'-GGAGGCATTCTTCAGGTTTGCTG-3'; RANKL: 5'-AGCTGCGAAGGGGCACATGA-3' and 5'-ACTGGATCCGGATCAGGATG-3'; TACE: 5'-CCATGAAGTGTTCCGATAGAT GTC-3' and 5'-ACCTGAAGAGCTTGTTCATCGAG-3'; and $\beta$-actin: 5'-CGATTTCCCGCTCGGCCGTGGTGGTGAAGC-3' and 5'-GGCGACGAGGCCCAGAGCAAGAGAGGCATC-3'. cDNA was amplified starting with $95^{\circ} \mathrm{C}$ for $10 \mathrm{~min}$, followed by 35 cycles of $94^{\circ} \mathrm{C}$ for $45 \mathrm{~s}, 60^{\circ} \mathrm{C}$ for $60 \mathrm{~s}$, and $72^{\circ} \mathrm{C}$ for $90 \mathrm{~s}$, and a final cycle of $72^{\circ} \mathrm{C}$ for $7 \mathrm{~min}$. The size of the PCR products for OPG, TACE, RANKL, and $\beta$-actin were 603, 190, 329, and $460 \mathrm{bp}$, respectively. A full-length OPG cDNA (1174 bp) was generated by RT-PCR using 5'-CCGGCCTCTTCGGCCGCCAAGCGAGAAACGTTTCCTCCAAAGTACC-3' and 5'-ACTAGTTATAAGCAGCTTATTTTTACTG-3' primers. The PCR product was gel-purified and ligated into pCR-XL-TOPO (Invitrogen, Basel, Switzerland).

Western blot analysis. Skimmed human milk (1:5), normal human serum (1:50), and rOPG (20 ng/lane; R\&D Systems), separated by $10 \%$ or $4 \%$ to $20 \%$ SDS-PAGE under reducing or nonreducing conditions, were transferred to nitrocellulose (BioRad, Glattbrugg, Switzerland). OPG was identified by incubation with the anti-OPG MAb, IMG-103 $(2 \mu \mathrm{g} / \mathrm{mL}$; Imgenex, AMS Biotechnology, Lugano, Switzerland) using WesternBreeze Chromogenic Detection kit (Invitrogen). Prestained protein markers were used as $M_{\mathrm{r}}$ standards (BioRad).

ELISA. OPG and sRANKL concentrations were determined by specific ELISA kits (Immunodiagnostik, Bensheim, Germany) with a detection limit of $\sim 0.14 \mathrm{pM}$ and $0.4 \mathrm{pM}$, respectively.

FACS analysis. Cell suspensions of MCF-7 were incubated at $4^{\circ} \mathrm{C}$ for $30 \mathrm{~min}$ with FITC-conjugated mouse anti-TACE MAb (R\&D Systems) or an isotype-matched Ab (IgG1; Becton-Dickinson, Heidelberg, Germany). Cells were analyzed on a FACScan flow cytometer (Becton-Dickinson) using CellQuest analysis software.

Cell viability assay. Jurkat cells $\left(5 \times 10^{4}\right.$ cells $/$ well $)$ were cultured in the presence of recombinant TRAIL ( 0 to 20 $\mathrm{ng} / \mathrm{mL}$; Alexis) and enhancer ( $2 \mu \mathrm{g} / \mathrm{mL}$; Alexis). Recombinant OPG (50 ng/mL; R\&D Systems) or human milk fractions (1:20) were added to specific wells with or without MAB805, an anti-OPG MAb (20 $\mu \mathrm{g} / \mathrm{mL}$; R\&D Systems), or its isotypematched control (IgG1; Sigma Chemical Co.). Plates were incubated for a total of $16 \mathrm{~h}$, with cell proliferation being measured by adding ${ }^{3} \mathrm{H}-\mathrm{TdR}(1 \mu \mathrm{Ci} / \mathrm{well})$ during the last $6 \mathrm{~h}$.

Bone pit resorption analysis. Bone cells were prepared from long bones of 10-d-old New-Zealand rabbits (Elevages Scientifiques des Dombes, France) as previously described (16). 
Briefly, bones were minced in $\alpha$-MEM (Sigma Chemical Co.), and the cells released by vigorous vortexing were collected in the supernatant after allowing a short sedimentation. The osteoclast-rich preparation was seeded into plates containing cortical bone slices in $\alpha$-MEM supplemented with $1 \%$ FCS. After $80 \mathrm{~min}$, nonadherent cells were removed and fresh medium was added. Recombinant OPG $(40 \mathrm{ng} / \mathrm{mL})$, human milk (1:20), and bovine colostrum or milk (1:25) was added to specific wells, in the presence or absence of recombinant RANKL (100 ng/mL; Alexis). After $72 \mathrm{~h}$ of incubation at $37^{\circ} \mathrm{C}$, bone slices were stained with toluidine blue- $1 \%$ borate, and the pit area was measured using a computer analysis system according to stereologic principles.

Gavage of rats. Suckling 5-d-old Sprague Dawley rat pups (Iffa-Credo, France) were gavaged with $0.3 \mathrm{~mL}$ of human milk $(n=10)$ or a rat milk substitute $(17)(n=10)$ or were kept with their mothers $(n=10)$. Blood samples were collected from five rats per group after $1.5 \mathrm{~h}$ and from the remaining five animals in each group after $4 \mathrm{~h}$.

Statistical analysis. Means were compared using one-way ANOVA, and multiple comparison tests were computed using Fisher's least significant difference on a 5\% significant level. Two means differing by more than the least significant difference are significantly different ( $\alpha=5 \%$ ).

\section{RESULTS}

Characterization of OPG in human milk. Samples of human milk obtained from healthy lactating mothers who delivered at term $(37-42 \mathrm{wk} ; n=87)$ or preterm $(<37 \mathrm{wk} ; n=6)$ were examined for their levels of OPG using a specific ELISA (Fig. 1A). In human milk from mothers who delivered at term, the range of OPG concentration in colostrum $(0-5 \mathrm{~d} ; n=23)$ was 2.8 to $40.6 \mathrm{nM}$ (mean, $14.4 \mathrm{nM}$ ), in transitional milk (6-30 $\mathrm{d} ; n=41$ ) was 0.7 to $39.9 \mathrm{nM}$ (mean, $9.3 \mathrm{nM}$ ), and in mature milk ( $>30 \mathrm{~d} ; n=23$ ) was 2.9 to $32.1 \mathrm{nM}$ (mean, $22.1 \mathrm{nM}$ ) (Fig. 1A). There was no significant correlation between the OPG concentration and the duration of lactation. In human milk $(0-22 \mathrm{~d} ; n=3)$ from mothers who delivered preterm, the range of OPG concentration was 1.7 to $17.8 \mathrm{nM}$ (mean, 7.0 $\mathrm{nM}$ ). Irrespective of the time in lactation, mean OPG levels in human milk samples were much higher than those observed in the serum during pregnancy $(5.08 \pm 1.60 \mathrm{pM})$ or lactation (at 3 and 6 mo postpartum; mean, $4.03 \pm 1.08 \mathrm{pM}$; Table 1 ) or in normal serum $(4.0 \pm 1.0 \mathrm{pM})$.

The nature of OPG in human milk samples collected up to day 71 postpartum was examined by immunoblot analysis (Fig. $1 B$ ). The apparent $M_{\mathrm{r}}$ of milk OPG was $\sim 58 \mathrm{kD}$ under reducing conditions and $\sim 190 \mathrm{kD}$ under nonreducing conditions. No monomeric form of OPG with a mass of $\sim 58 \mathrm{kD}$ was detected under nonreducing conditions. Under reducing conditions, the OPG migrated even slower than the expected homodimeric form. Similar results were obtained when normal human serum was used, although additional minor bands were observed. Of note, the rOPG used as positive control was generated as a chimeric protein and therefore has an apparent $M_{\mathrm{r}}$ of $\sim 80 \mathrm{kD}$ under reducing conditions. In milk fractions, OPG was de-
A

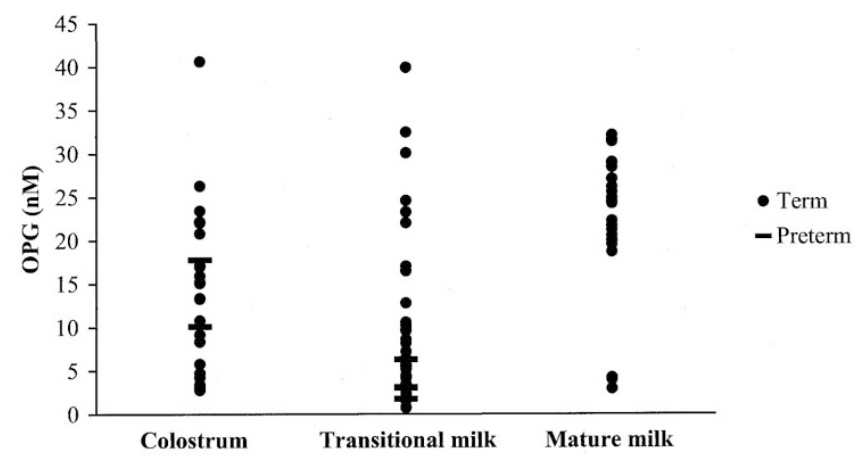

B

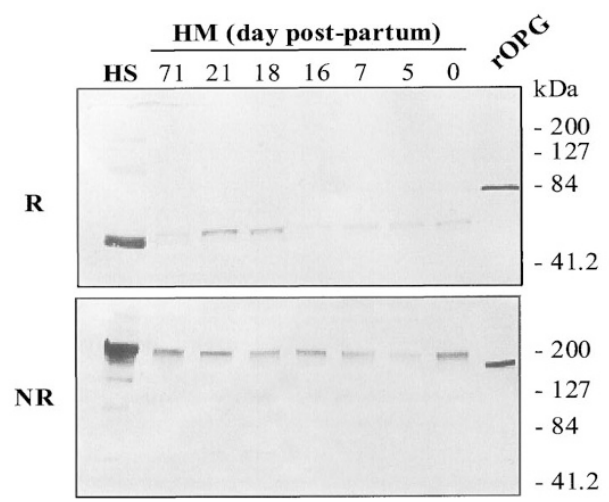

Figure 1. Characterization of milk OPG. $(A)$ Levels of OPG determined by ELISA in colostrum and in transitional and mature milk samples from mothers who delivered at term or preterm. (B) Immunoblot for OPG in human milk $(\mathrm{HM})$ at different times during lactation under reducing (R; top) and nonreducing conditions (NR; bottom). Normal human serum (HS) and recombinant OPG (rOPG) were added as controls. The migration of $M_{\mathrm{r}}$ standards $(\mathrm{kD})$ is indicated.

Table 1. Concentrations of $O P G$ in human serum and milk during pregnancy and lactation

\begin{tabular}{ccc}
\hline & \multicolumn{2}{c}{ OPG* $^{*}$} \\
\cline { 2 - 3 } & Serum $(\mathrm{pM})$ & Milk $(\mathrm{nM})$ \\
\hline Pregnancy & & $\mathrm{NA}$ \\
$8 \mathrm{mo}$ & $5.08 \pm 1.60$ & \\
Postpartum & $\mathrm{NT}$ & $20.67 \pm 8.48$ \\
$5 \mathrm{~d}$ & $\mathrm{NT}$ & $21.79 \pm 10.53$ \\
$1 \mathrm{mo}$ & $3.99 \pm 0.95$ & $22.76 \pm 3.31$ \\
$3 \mathrm{mo}$ & $4.07 \pm 1.24$ & $26.98 \pm 4.33$ \\
$6 \mathrm{mo}$ &
\end{tabular}

* Data represent mean \pm SD of 10 samples tested by ELISA. NA, not applicable; NT, not tested.

tected in skimmed milk, cream, and whey but not in casein fractions (data not shown).

Mammary epithelial cells and milk cells are potential sources of milk $\boldsymbol{O P G}$. To identify the cellular source of milk OPG, we investigated whether OPG mRNA was expressed in the human mammary epithelial cell line MCF-7 and/or in HBMC. A single band of the expected size (603 bp) was detected in each sample (Fig. $2 A$ ). Furthermore, we cloned the full-length OPG cDNA product obtained from HBMC and found that this coded for the mature form of OPG. 
A

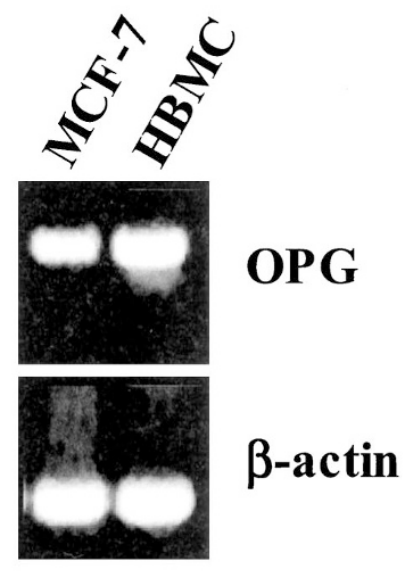

B

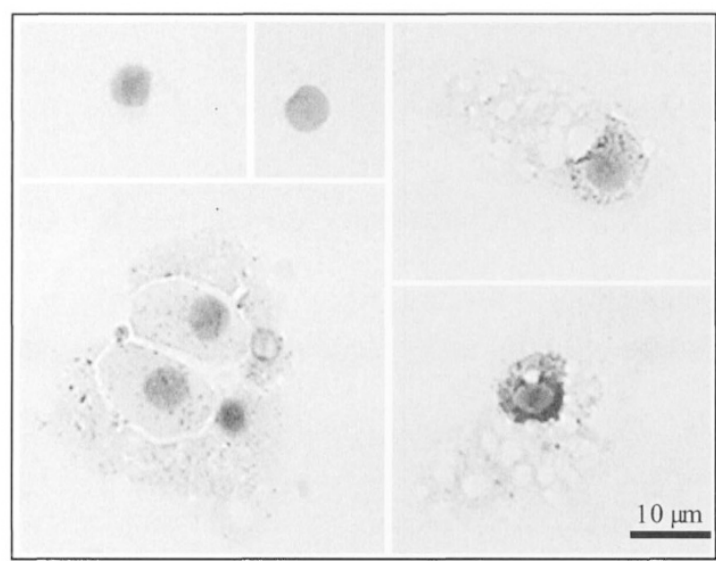

Figure 2. Expression of OPG by HBMC and mammary epithelial cells. (A) RT-PCR analysis of mRNAs for OPG and $\beta$-actin in MCF-7 and HBMC. (B) Immunocytochemical study of OPG expression in human milk lymphocytes (top left), epithelial cells (bottom left), and macrophages (right) from cytospins counterstained with Mayer's hematoxylin.

We then assessed the protein expression by HBMC and MCF-7 cells. Immunocytochemical staining with a specific anti-OPG antibody revealed the expression in epithelial cells and macrophages of HBMC (Fig. 2B). Furthermore, specific ELISA revealed the presence of OPG protein in the culture supernatant of MCF-7 (Fig. 3). The modulatory effects of factors known to regulate OPG expression [see review (18) and Refs. $(19,20)]$ were studied in MCF-7 cells (Fig. 3). Treatment of the cells for $48 \mathrm{~h}$ in the presence of $17 \beta$-estradiol, 1,25 dihydroxyvitamin $\mathrm{D}_{3}$, PTH (all $10^{-7} \mathrm{M}$ ), IL-18, or TGF- $\beta$ (5 $\mathrm{ng} / \mathrm{mL}$ ) had no effect on OPG expression by MCF-7. In contrast, treatment with TNF- $\alpha(10 \mathrm{ng} / \mathrm{mL}), \mathrm{IL}-1 \beta(25 \mathrm{U} / \mathrm{mL})$, or leptin $(2 \mu \mathrm{g} / \mathrm{mL})$ induced, respectively, an $\sim 10$-fold, 5 -fold, and 2- to 3-fold increase in OPG when compared with untreated cells.

Milk OPG blocked TRAIL-induced inhibition of Jurkat cell proliferation. To test whether milk OPG was biologically

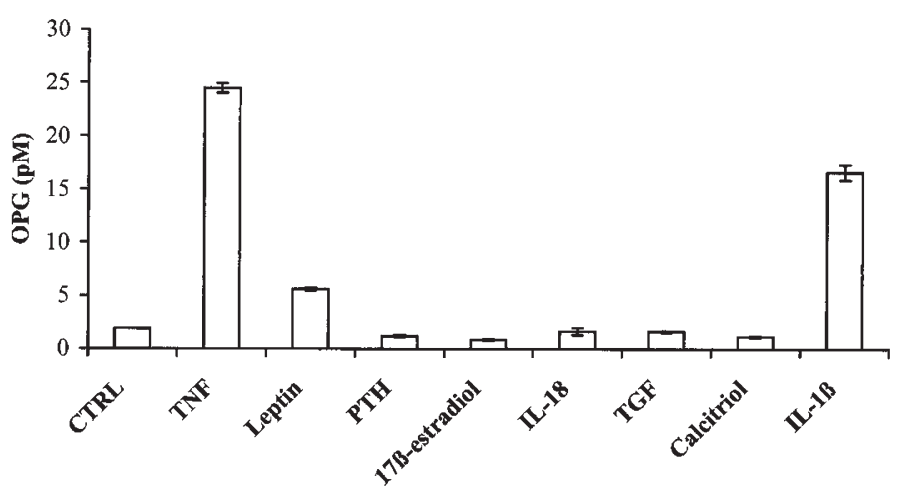

Figure 3. Regulation of OPG expression in mammary epithelial cells. Concentration by ELISA of OPG in the supernatant of MCF-7 cells incubated with TNF- $\alpha$, leptin, PTH, $17 \beta$-estradiol, IL-18, IL- $1 \beta$, TGF- $\beta$, or calcitriol or in normal cell culture medium (CTRL). Results are expressed as means $\pm \mathrm{SD}$ of duplicate cultures.

active, we examined its capacity to modulate TRAIL-induced apoptosis of the Jurkat cell line (9). More specific, we measured its effect on the incorporation of ${ }^{3} \mathrm{H}$ thymidine by Jurkat cells cultured in the presence of increasing doses of TRAIL (Fig. 4). As expected, rOPG specifically reversed the TRAILinduced inhibition of Jurkat cell proliferation (Fig. 4A). Exposure of Jurkat cells to either skimmed human milk or sweet whey also inhibited the effect of TRAIL on Jurkat cell proliferation (Fig. 4B). Anti-OPG MAb but not its isotype-matched control reversed the effect of the milk fractions as well as that of the rOPG. The casein fraction, which does not contain OPG, had no effect on TRAIL-induced inhibition of Jurkat cell proliferation.

Milk OPG inhibits osteoclast-mediated bone resorption in vitro. Milk OPG was also tested for its ability to suppress osteoclast-mediated bone resorption in an in vitro rabbit pit assay. Bone-resorbing activity was significantly decreased by human milk (77\%), bovine colostrum (day 2 postpartum; $52 \%$ ), and bovine milk (day 10 postpartum; $50 \%$ ), as well as by rOPG (44\% inhibition; Fig. 5). The addition of recombinant RANKL had no effect when given alone (9\% inhibition), but it significantly decreased the inhibition of bone-resorbing activity mediated by rOPG from $44 \%$ to $4 \%$, that mediated by human milk from $77 \%$ to $54 \%$, that of bovine colostrum from $52 \%$ to $29 \%$, and that of bovine milk from $50 \%$ to $27 \%$. Indeed, two levels of inhibition differing by $>15 \%$ were considered significantly different $(\alpha=5 \%)$. That RANKL only partially reversed the effects of milk samples suggests that the milk contains antiresorptive agents besides OPG.

Milk OPG crosses the gastrointestinal tract. For examining whether milk-derived OPG reaches extraintestinal tissues, rat pups were gavaged with human milk and their blood was subsequently examined for the presence of OPG using an ELISA specific for human OPG. A small but significant amount of OPG was detected after $1.5 \mathrm{~h}$ (4.20 and $9.37 \mathrm{pM})$ or $4 \mathrm{~h}(2.85$ and $3.95 \mathrm{pM})$ in the plasma of some pups that were gavaged with human milk. As expected, human milk-derived OPG was not detected in the blood of rats that received an artificial milk substitute or in that of suckling pups (Table 2). This preliminary experiment suggests that milk-derived OPG 


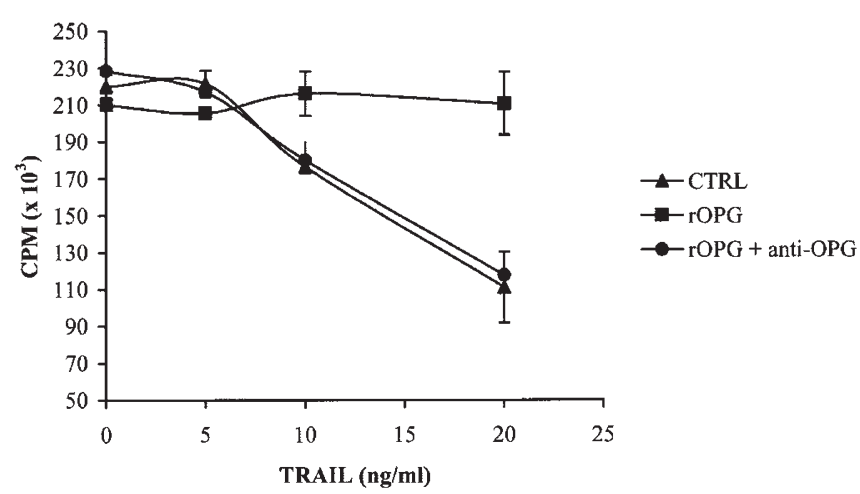

B

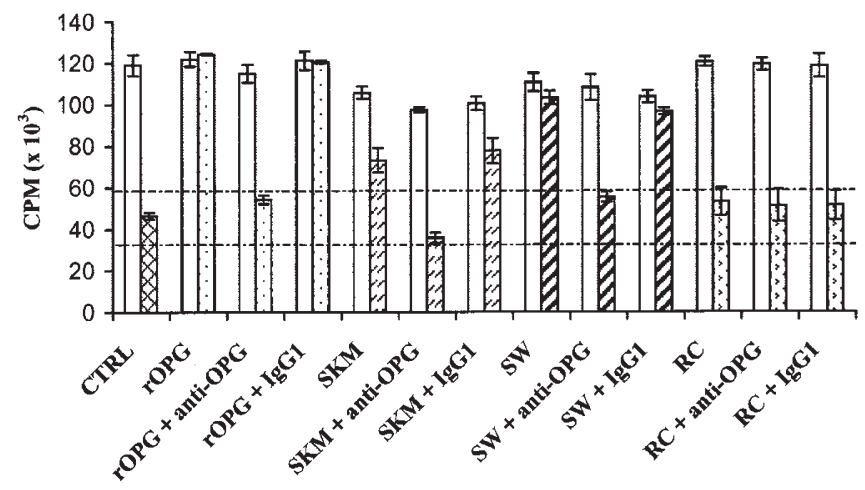

Figure 4. Effect of milk OPG on TRAIL-induced inhibition of Jurkat cell proliferation. $(A)$ Proliferation of Jurkat cells treated with increasing amounts of TRAIL alone (CTRL), in the presence of rOPG or in the presence of rOPG plus an anti-OPG MAb. (B) Proliferation of Jurkat cells treated with (filled bars) or without (open bars) TRAIL and in the presence of rOPG, human skimmed milk (SKM), sweet whey (SW), or rennet casein (RC) with or without an anti-OPG MAb or its IgG1 isotype-matched control. Results are expressed as means $\pm \mathrm{SD}$ of triplicate cultures of one experiment representative of four. The area between the two dotted lines represents the limit of significant difference with the CTRL.

Table 2. Detection of human milk-derived $O P G$ in serum of neonatal rats gavaged with human milk

\begin{tabular}{lccc}
\hline & \multicolumn{3}{c}{ Gavage type* } \\
\cline { 2 - 4 } Time after gavage & Human milk & Rat milk substitute & None \\
\hline $1.5 \mathrm{~h}$ & $2 / 5$ & $0 / 2$ & $0 / 2$ \\
$\quad$ Detectable/analyzed $\dagger$ & $\mathrm{ND}-9.37$ & $\mathrm{ND}$ & $\mathrm{ND}$ \\
$\quad$ Range $\dagger$ & & & \\
$4 \mathrm{~h}$ & $2 / 5$ & $0 / 2$ & $0 / 2$ \\
$\quad$ Detectable/analyzed $\dagger$ & $\mathrm{ND}-3.95$ & $\mathrm{ND}$ & $\mathrm{ND}$ \\
$\quad$ Range $\dagger$ & & & \\
\hline
\end{tabular}

$\mathrm{ND}$, not detectable.

* Neonatal rats were gavaged as described in "Methods." Blood samples were collected from five rats per group after $1.5 \mathrm{~h}$ and from the remaining five animals in each group after $4 \mathrm{~h}$.

$\dagger$ The total number of samples tested at each time point and those with detectable levels of OPG are indicated.

$\ddagger$ Data represent OPG levels (pM) in blood samples tested by ELISA.

administered orally may be absorbed across the gastrointestinal tract to reach the systemic circulation.

Expression of RANKL and TNF- $\alpha$-converting enzyme by MCF-7 cells and human milk cells. Because the balance

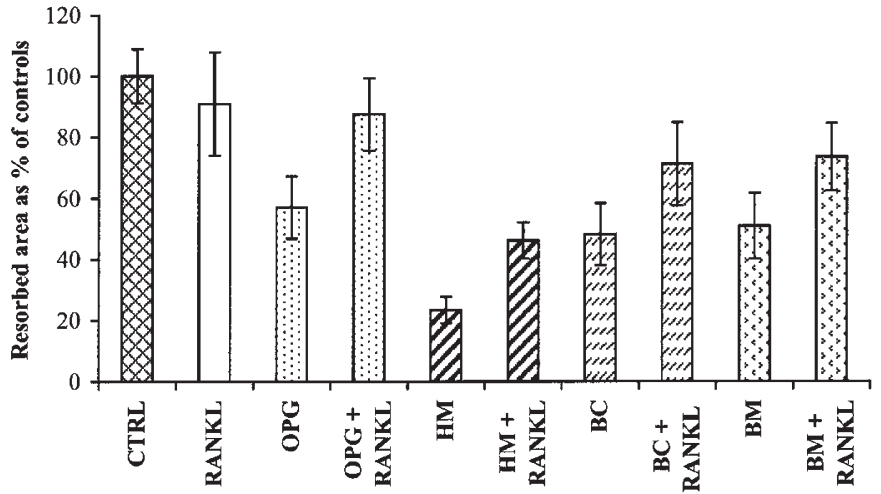

Figure 5. Effect of milk OPG on osteoclast activity. Resorbed area as percentage of controls observed on bone slices cultured with osteoclast-rich populations in culture medium (CTRL) supplemented human rOPG, human milk (HM), bovine colostrum (BC), or bovine milk (BM) with or without the addition of human RANKL. Results are expressed as means \pm SD of one experiment representative of three.

between OPG and RANKL critically determines biologic outcome, we also investigated the expression of the latter and of the TNF- $\alpha$-converting enzyme (TACE), which is involved in release of RANKL from the plasma membrane (21). Both MCF-7 and HBMC constitutively expressed the mRNAs for RANKL and TACE (expected size band $329 \mathrm{bp}$ and $190 \mathrm{bp}$, respectively; Fig. $6 A$ ). FACS analysis demonstrated the expression of TACE protein (Fig. 6B) but not of RANKL (data not shown) on the surface of MCF-7 cells. Furthermore, using a specific ELISA, we were unable to detect soluble RANKL in either the cell culture supernatant of MCF-7 or in human milk.

\section{DISCUSSION}

The protein components of human milk contribute to many of the important nutritional and physiologic functions associated with breast-feeding. Among these proteins are secretory IgA, lactoferrin, lysozyme, cytokines that participate in host defense mechanisms, and an array of growth factors such as IGF, TGF- $\beta$, and other factors that play an important role in osteogenesis. Here, we provide direct evidence for the presence of a large amount of active OPG in human milk. OPG is present in human milk samples at different times during lactation in concentrations that are up to 1000-fold higher than that found in normal human serum. No significant differences were observed between milk collected from mothers of premature versus term infants.

OPG has been described as both a monomer and a homodimer $(6,7,22)$. We found that the OPG protein in both human milk and human normal serum seemed to be predominantly in a disulfide-linked trimeric or tetrameric form, suggesting that the molecule might exhibit unusual disulfide bonding and/or glycosylation. Our finding on the serum is in contrast to the report of Yano et al. (23), which showed that OPG circulates predominantly in a monomeric form. The reason for this discrepancy is unknown. However, it is possible that in the Japanese study, there was a conversion of polymeric OPG into monomeric OPG by protease(s) involved in blood coagulation or by fibrinolysis during the preparation of the blood samples. 
A
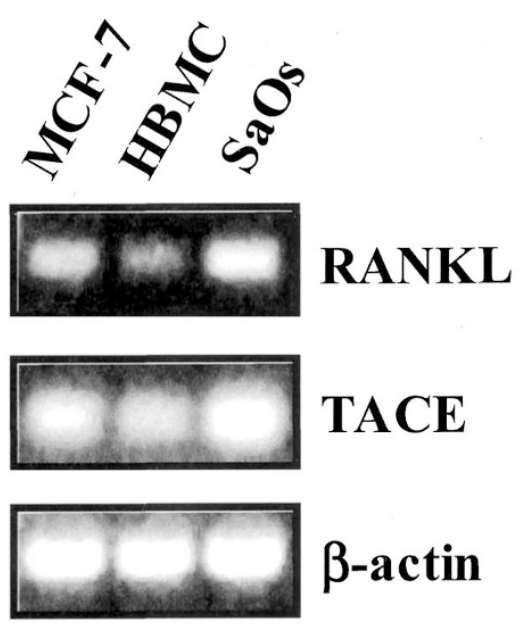

B

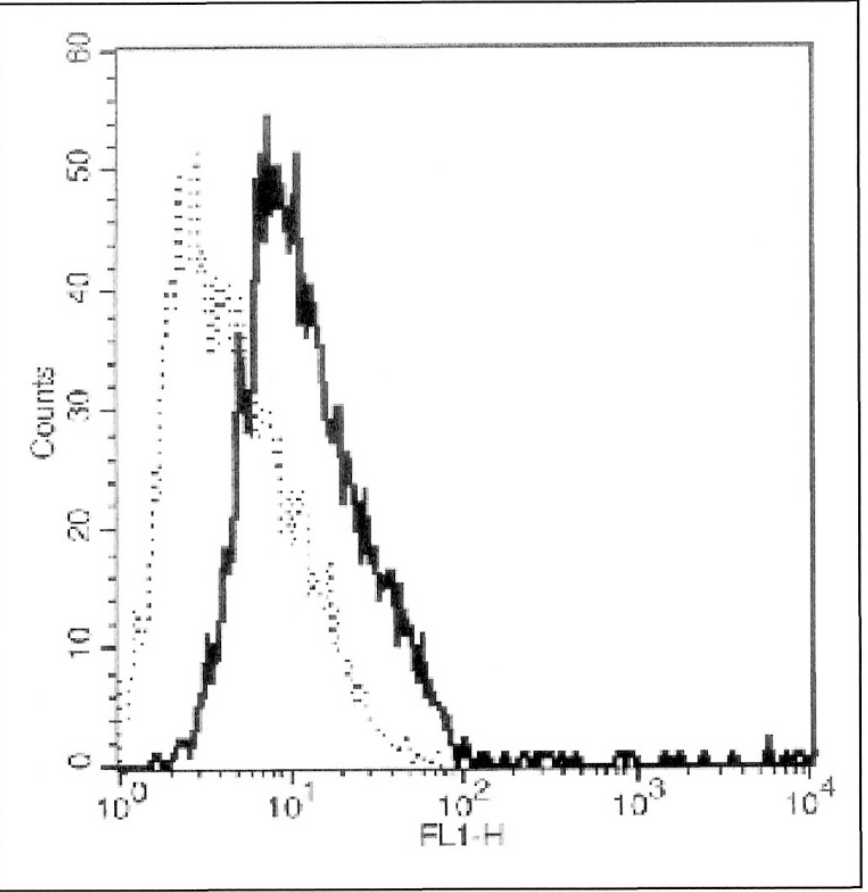

Figure 6. Expression of RANKL and TACE by HBMC and mammary epithelial cells. (A) RT-PCR analysis of mRNA for RANKL, TACE, and $\beta$-actin in MCF-7, HBMC, and human osteogenic sarcoma cells (SaOs). (B) FACS analysis of cell surface binding of anti-TACE MAbs (solid line) or isotype control $\mathrm{Ab}$ (dotted line) to MCF-7 cells. Fluorescence intensity values are shown on the $x$ axis

Both mammary gland epithelial cells and HBMC are potential sources of milk OPG. In agreement with a recent report (15), we found that OPG protein is secreted by cultured human mammary gland epithelial cells, MCF-7. However, we also found that HBMC expressed mRNA for OPG. The HBMC population contains epithelial cells, phagocytes, and lymphocytes. Phagocytes predominate early in lactation, but mammary epithelial cells shed into milk are the predominant cell type after the second month of lactation (24). We found that milk epithelial cells and phagocytes but not milk lymphocytes expressed OPG. The lack of OPG expression by milk lympho- cytes is coherent with the observation that OPG is not expressed in peripheral blood lymphocytes (13). It is interesting that it has been reported that milk epithelial cells exhibit characteristics of viable, differentiated alveolar epithelial cells $(25,26)$, suggesting that these cells could be regulated to produce and secrete OPG in situ.

We have considered that the high concentration of OPG in human milk compared with human serum may be a consequence of an increased OPG in maternal blood finding its way into the milk. To date, the cellular source of circulating OPG is not known, and the mechanisms that regulate the levels in serum have not been described. Nevertheless, it has been reported that the concentration of circulating OPG markedly increases in the mouse during pregnancy and that it may serve to protect against excess bone resorption prepartum (27). Recently, a study in humans also showed that the concentrations of serum OPG in mothers steadily increases during pregnancy. However, the levels immediately before delivery were only $\sim 2.5$ times higher than those in nonpregnant, nonpuerperal women and fell rapidly after delivery (28). In our study, serum OPG concentrations in mothers at 8 mo gestation and during lactation were not significantly different from those reported for normal human donors. Thus, the high levels in milk may be due to increased local production by the mammary gland and/or the milk cellular compartment.

A number of factors, including hormones, growth factors, and inflammatory mediators, have the capacity to up-regulate OPG expression in human bone marrow stromal cells and osteoblasts [for review, see Ref. (18)]. Of these, TNF- $\alpha$, IL-1 $\beta$, and leptin have been found in human colostrum and milk (29, 30). Furthermore, it has been shown that TNF, which is expressed by rat mammary epithelial cells in a developmentally regulated manner, is a physiologically significant regulator of mammary gland development and of milk protein gene expression (31). We describe herein that treatment of mammary epithelial cells with these cytokines resulted in increased OPG expression. These findings suggest that in vivo, TNF, IL-1 $\beta$, and/or the leptin present in human milk or mammary tissue may regulate production of OPG by mammary epithelial cells.

Given the known effects of OPG on bone remodeling, we tested the capacity of milk OPG to inhibit the activity of mature osteoclasts in an in vitro bone resorption assay. Human milk and bovine colostrum and milk inhibited osteoclast activity in a manner that was partially reversed by the addition of soluble RANKL. It is clear that milk might contain components, other than OPG, that can down-regulate osteoclast activity. Because all genetic and functional experiments indicate that the balance between RANKL-OPG regulates development and activation of osteoclasts and bone metabolism $(6,32)$, we considered that human milk may also contain a soluble form of RANKL. In contrast to a previous report (15), we found that MCF-7 cells express specific mRNA for RANKL, but we were unable to detect any protein expression at the cell surface. Consequently, we assessed the expression of the metalloprotease-disintegrin TACE, which is known to play a role in the shedding of RANKL from the plasma membrane (21). Although, MCF-7 constitutively expressed TACE, we failed to detect RANKL in 
either the cell culture supernatant or milk samples. This may be due to insufficient sensitivity of the ELISA test that we used, and it is also feasible that the substantial amounts of OPG present in both fluids may bind any soluble RANKL present and thereby reduce the amount of "free" RANKL available for detection.

In addition to the regulatory effects of the RANKL/RANK/ OPG system on bone remodeling, a number of studies have highlighted the involvement of this system in immune responses. Binding of RANKL to RANK augments dendritic cell survival, enhances the stimulatory capacity of dendritic cells, and modulates activated T cells (2-4, 33). Furthermore, OPG is critically involved in B cell maturation and the generation of efficient antibody responses (12). An additional role of OPG in immune responses is related to binding to its ligand TRAIL. Although the in vivo role of TRAIL remains to be determined, it is a potent activator of apoptosis in certain cells after binding to its receptors (34). Recently, it was reported that apoptosis mediated by TRAIL is critical in determining the fate of differentiating $\mathrm{T}$ helper cells, Th1 cells being more sensitive to TRAIL-induced apoptosis than Th2 cells (35). Certainly, milk OPG interacted with TRAIL in our model of TRAIL-induced inhibition of Jurkat cell proliferation. It follows, therefore, that milk OPG could influence immune homeostasis by regulating the Th1/Th2 balance.

The functions of many of the bioactive proteins in milk remain to be elucidated, but it is likely that certain of them influence both the function of the mammary gland and the growth and development of various neonatal tissues. In addition to their role in bone homeostasis and immunobiology, RANK-RANKL interactions are critical for the development of the lactating mammary gland during pregnancy and for the expression of the $\beta$-casein gene in mammary epithelial cells (36). It follows, therefore, that OPG in mammary tissue or in milk may exert some influence on such interactions.

If, as suggested by our gavage experiments in neonatal rats, milk OPG survives gastrointestinal passage and crosses the intestinal epithelium to be absorbed into the circulation, then it is tempting to speculate that it may modulate RANKL/RANK and TRAIL/TRAIL-R interactions, not only in the intestine lumen but also in underlying tissues. This being the case, the OPG-like activity of bovine milk not only may be exploited in products to regulate bone remodeling and immune responses in the infant, it may also provide a new and natural alternative therapy in instances of immune dysregulation and excessive bone resorption.

Acknowledgments. We thank Dr. A. Rytz for help in the statistical analyses and P. Serrant, B. Schlosser, N. Pitton, O. Morandi, and J. Clough for excellent technical assistance.

\section{REFERENCES}

1. Anderson DM, Maraskovsky E, Billingsley WL, Dougall WC, Tometsko ME, Roux ER, Teepe MC, DuBose RF, Cosman D, Galibert L 1997 A homologue of the TNF receptor and its ligand enhance T-cell growth and dendritic-cell function. Nature 390:175-179

2. Wong BR, Josien R, Lee SY, Sauter B, Li HL, Steinman RM, Choi Y 1997 TRANCE (tumor necrosis factor [TNF]-related activation-induced cytokine), a new TNF family member predominantly expressed in T cells, is a dendritic cell-specific survival factor. J Exp Med 186:2075-2080

3. Kong YY, Yoshida H, Sarosi I, Tan HL, Timms E, Capparelli C, Morony S, Oliveira-dos-Santos A, Van G, Itie A, Khoo W, Wakeham A, Dunstan CR, Lacey DL, Mak TW, Boyle WJ, Penninger JM 1999 OPGL is a key regulator of osteoclastogenesis, lymphocyte development and lymph-node organogenesis. Nature 397:315323

4. Dougall WC, Glaccum M, Charrier K, Rohrbach K, Brasel K, De Smedt T, Daro E, Smith J, Tometsko ME, Maliszewski CR, Armstrong A, Shen V, Bain S, Cosman D, Anderson D, Morrissey PJ, Peschon JJ, Schuh J 1999 RANK is essential for osteoclast and lymph node development. Genes Dev 13:2412-2424

5. Lacey DL, Timms E, Tan HL, Kelley MJ, Dunstan CR, Burgess T, Elliott R, Colombero A, Elliott G, Scully S, Hsu H, Sullivan J, Hawkins N, Davy E, Capparelli C, Eli A, Qian YX, Kaufman S, Sarosi I, Shalhoub V, Senaldi G, Guo J, Delaney J, Boyle WJ 1998 Osteoprotegerin ligand is a cytokine that regulates osteoclast differentiation and activation. Cell 93:165-176

6. Simonet WS, Lacey DL, Dunstan CR, Kelley M, Chang MS, Luthy R, Nguyen HQ, Wooden S, Bennett L, Boone T, Shimamoto G, DeRose M, Elliott R, Colombero A, Tan HL, Trail G, Sullivan J, Davy E, Bucay N, Renshaw-Gegg L, Hughes TM, Hill D, Pattison W, Campbell P, Boyle WJ 1997 Osteoprotegerin: a novel secreted protein involved in the regulation of bone density. Cell 89:309-319

7. Tsuda E, Goto M, Mochizuki S, Yano K, Kobayashi F, Morinaga T, Higashio K 1997 Isolation of a novel cytokine from human fibroblasts that specifically inhibits osteoclastogenesis. Biochem Biophys Res Commun 234:137-142

8. Yasuda H, Shima N, Nakagawa N, Mochizuki SI, Yano K, Fujise N, Sato Y, Goto M, Yamaguchi K, Kuriyama M, Kanno T, Murakami A, Tsuda E, Morinaga T, Higashio K 1998 Identity of osteoclastogenesis inhibitory factor (OCIF) and osteoprotegerin (OPG): a mechanism by which OPG/OCIF inhibits osteoclastogenesis in vitro. Endocrinology 139:1329-1337

9. Emery JG, McDonnell P, Burke MB, Deen KC, Lyn S, Silverman C, Dul E, Appelbaum ER, Eichman C, DiPrinzio R, Dodds RA, James IE, Rosenberg M, Lee JC, Young PR 1998 Osteoprotegerin is a receptor for the cytotoxic ligand TRAIL. J Biol Chem 273:14363-14367

10. Wiley SR, Schooley K, Smolak PJ, Din WS, Huang CP, Nicholl JK, Sutherland GR, Smith TD, Rauch C, Smith CA 1995 Identification and characterization of a new member of the TNF family that induces apoptosis. Immunity 3:673-682

11. Mizuno A, Amizuka N, Irie K, Murakami A, Fujise N, Kanno T, Sato Y, Nakagawa N, Yasuda H, Mochizuki S, Gomibuchi T, Yano K, Shima N, Washida N, Tsuda E, Morinaga T, Higashio K, Ozawa H 1998 Severe osteoporosis in mice lacking osteoclastogenesis inhibitory factor/osteoprotegerin. Biochem Biophys Res Commun 247:610-615

12. Yun TJ, Tallquist MD, Aicher A, Rafferty KL, Marshall AJ, Moon JJ, Ewings MK, Mohaupt M, Herring SW, Clark EA 2001 Osteoprotegerin, a crucial regulator of bone metabolism, also regulates B cell development and function. J Immunol 166:14821491

13. Yun TJ, Chaudhary PM, Shu GL, Frazer JK, Ewings MK, Schwartz SM, Pascual V, Hood LE, Clark EA 1998 OPG/FDCR-1, a TNF receptor family member, is expressed in lymphoid cells and is up-regulated by ligating CD40. J Immunol 161:6113-6121

14. Tan KB, Harrop J, Reddy M, Young P, Terrett J, Emery J, Moore G, Truneh A 1997 Characterization of a novel TNF-like ligand and recently described TNF ligand and TNF receptor superfamily genes and their constitutive and inducible expression in hematopoietic and non-hematopoietic cells. Gene 204:35-46

15. Thomas RJ, Guise TA, Yin JJ, Elliott J, Horwood NJ, Martin TJ, Gillespie MT 1999 Breast cancer cells interact with osteoblasts to support osteoclast formation. Endocrinology 140:4451-4458

16. Lorget F, Mentaverri R, Meddah B, Cayrolle G, Wattel A, Morel A, Schecroun N, Maamer M, de Vernejoul MC, Kamel S, Brazier M 2000 Evaluation of in vitro bone resorption: high-performance liquid chromatography measurement of the pyridinolines released in osteoclast cultures. Anal Biochem 284:375-381

17. Dvorak B, McWilliam DL, Williams CS, Dominguez JA, Machen NW, McCuskey RS, Philipps AF 2000 Artificial formula induces precocious maturation of the small intestine of artificially reared suckling rats. J Pediatr Gastroenterol Nutr 31:162-169

18. Hofbauer LC, Heufelder AE 2001 Role of receptor activator of nuclear factor- $\kappa$ B ligand and osteoprotegerin in bone cell biology. J Mol Med 79:243-253

19. Makiishi-Shimobayashi C, Tsujimura T, Iwasaki T, Yamada N, Sugihara A, Okamura H, Hayashi SS, Terada N 2001 Interleukin-18 up-regulates osteoprotegerin expression in stromal/osteoblastic cells. Biochem Biophys Res Commun 281:361-366

20. Burguera B, Hofbauer LC, Thomas T, Gori F, Evans GL, Khosla S, Riggs BL, Turner RT 2001 Leptin reduces ovariectomy-induced bone loss in rats. Endocrinology 142:3546-3553

21. Lum L, Wong BR, Josien R, Becherer JD, Erdjument-Bromage H, Schlondorff J, Tempst P, Choi Y, Blobel CP 1999 Evidence for a role of a tumor necrosis factor-alpha (TNF-alpha)-converting enzyme-like protease in shedding of TRANCE, a TNF family member involved in osteoclastogenesis and dendritic cell survival. J Biol Chem 274:13613-13618

22. Tomoyasu A, Goto M, Fujise N, Mochizuki S, Yasuda H, Morinaga T, Tsuda E, Higashio K 1998 Characterization of monomeric and homodimeric forms of osteoclastogenesis inhibitory factor. Biochem Biophys Res Commun 245:382-387

23. Yano K, Tsuda E, Washida N, Kobayashi F, Goto M, Harada A, Ikeda K, Higashio K, Yamada Y 1999 Immunological characterization of circulating osteoprotegerin osteoclastogenesis inhibitory factor: increased serum concentrations in postmenopausal women with osteoporosis. J Bone Miner Res 14:518-527

24. Brooker BE 1980 The epithelial cells and cell fragments in human milk. Cell Tissue Res 210:321-332 
25. Gaffney EV, Polanowski FP, Blackburn SE, Lambiase JP 1976 Origin, concentration and structural features of human mammary gland cells cultured from breast secretions. Cell Tissue Res 172:269-279

26. Taylor-Papadimitriou J, Shearer M, Tilly R 1977 Some properties of cells cultured from early-lactation human milk. J Natl Cancer Inst 58:1563-1571

27. Yano K, Shibata O, Mizuno A, Kobayashi F, Higashio K, Morinaga T, Tsuda E 2001 Immunological study on circulating murine osteoprotegerin/osteoclastogenesis inhibitory factor $(\mathrm{OPG} / \mathrm{OCIF})$ : possible role of $\mathrm{OPG} / \mathrm{OCIF}$ in the prevention of osteoporosis in pregnancy. Biochem Biophys Res Commun 288:217-224

28. Uemura H, Yasui T, Kiyokawa M, Kuwahara A, Ikawa H, Matsuzaki T, Maegawa M Furumoto H, Irahara M 2002 Serum osteoprotegerin/osteoclastogenesis-inhibitory factor during pregnancy and lactation and the relationship with calcium-regulating hormones and bone turnover markers. J Endocrinol 174:353-359

29. Srivastava MD, Srivastava A, Brouhard B, Saneto R, Groh-Wargo S, Kubit J 1996 Cytokines in human milk. Res Commun Mol Pathol Pharmacol 93:263-287

30. Casabiell X, Pineiro V, Tome MA, Peino R, Dieguez C, Casanueva FF 1997 Presence of leptin in colostrum and/or breast milk from lactating mothers: a potential role in the regulation of neonatal food intake. J Clin Endocrinol Metab 82:4270-4273
31. Ip MM, Shoemaker SF, Darcy KM 1992 Regulation of rat mammary epithelial cell proliferation and differentiation by tumor necrosis factor-alpha. Endocrinology 130:2833-2844

32. Bucay N, Sarosi I, Dunstan CR, Morony S, Tarpley J, Capparelli C, Scully S, Tan HL, Xu W, Lacey DL, Boyle WJ, Simonet WS 1998 Osteoprotegerin-deficient mice develop early onset osteoporosis and arterial calcification. Genes Dev 12:1260-1268

33. Josien R, Li HL, Ingulli E, Sarma S, Wong BR, Vologodskaia M, Steinman RM, Choi Y 2000 TRANCE, a tumor necrosis factor family member, enhances the longevity and adjuvant properties of dendritic cells in vivo. J Exp Med 191:495-502

34. Degli-Esposti M 1999 To die or not to die - the quest of the TRAIL receptors. J Leukoc Biol 65:535-542

35. Zhang XR, Zhang LY, Devadas S, Li L, Keegan AD, Shi YF 2003 Reciprocal expression of TRAIL and CD95L in Th1 and Th2 cells: role of apoptosis in Thelper subset differentiation. Cell Death Differ 10:203-210

36. Fata JE, Kong YY, Li J, Sasaki T, Irie-Sasaki J, Moorehead RA, Elliott R, Scully S, Voura EB, Lacey DL, Boyle WJ, Khokha R, Penninger JM 2000 The osteoclast differentiation factor osteoprotegerin-ligand is essential for mammary gland development. Cell 103:41-50 